\title{
VYSOKOŠKOLSKÁ ODBORNOST VERSUS POŽADAVKY TRHU NA KVALITU EDUKACE
}

\author{
Oldřich Berka, Pavla Sýkorová, Emanuel Šustek
}

Klíčová slova:

vzdělávání, trh práce, požadavky trhu práce na dovednosti absolventů škol, sociální a intelektové dovednosti, deskriptory EQF

\section{Key words:}

education, job market requirements for graduate skills, social and intelectual skills, EQF descriptors

\begin{abstract}
Abstrakt
Esej analyzuje vztah mezi trhem práce a edukací, zjištuje, zda a do jaké míry je trh (zaměstnavatelé) kritériem kvality vysoké školy. Je sondou do vývoje vztahů mezi prací a kvalitou vysokoškolského kurikula od počátku tzv. „masifikace“ vzdělávání, tj. od poloviny 20. století. Identifikuje 3 etapy tohoto vztahu: (1) potlačení sociální nerovnosti na vysokých školách (do konce 60. let); (2) projevující se zásadní nesoulad mezi sektorem práce a edukací (70. - 80. léta); (3) nastolení požadavku, aby školství přebíralo odpovědnost za výcvik dovedností (90. léta do současnosti).

Srovnává výzkum v dané oblasti (Porrer, Univerzita Edinburg, a deskriptory EQF). Autoři studie ukazují, že původní evaluace kvality vysokých škol, založené na vědním obsahu, ustupují požadavkům trhu na sociální a intelektové dovednosti, které představují hlavní kritéria kvality edukace.
\end{abstract}

\begin{abstract}
The team of this study authors analyses the relations between the work and education from the middle of the 20th century (the 50s) and try to find out (define) wether or to which extent the market requirements are an important criterium of the higher school quality. It is a depth probe into the development of these relations and as a result it identifies 3 periods of these relations: (1) reduction of the social inequality among the higher schools students(till the end of the 60s); (2) fundamentals discords between work (employees) and education going through (during the 70s-80s); (3) establishing the market priorities: the education takes over the responsibility for training skills for the work (90s - till today).

It compares research done in this field (Porrer, University Edinburgh) with the current descriptors of the European Qualification Framework (EQF). The study authors prove that the traditional evaluation of the higher school study, based on scientific contents, make way to the work skills as a main quality criterium of education.
\end{abstract}

\section{Úvod}

V průběhu devadesátých let do současnosti je stále více diskutována otázka kvality vzdělávání na vysokých školách. Úhel pohledu je dán především požadavkem na znalost obsahů edukace a na konkrétní vědomosti a znalosti. Jde o tradicí daný způsob hodnocení, a málokdo si uvědomuje paradigma tohoto postupu, které na původních středověkých univerzitách do značné míry představovala schopnost doslovného memorování učebních textů. Kurikulum vyššího studia se postupně proměňuje - jeho konfesijním rozštěpením na katolické a reformované, postupným pronikáním vědy do vzdělávacích obsahů za osvícenectví, jeho zpevněním humboldtovskými reformami ve střední Evropě a nakonec přechodem 
od výlučnosti k masovosti v druhé polovině 20. století. Univerzitní studia byla ovšem kritizována po celou dobu svého trvání, takže vývoj kritiky vyššího školství může tvořit samostatnou kapitolu vysokoškolského vzdělávání v Evropě.

V současnosti se k těmto kritériím přiřazují hodnocení vyučujících, studentů, posuzuje se množství zahraničních výjezdů, publikační činnost a v devadesátých letech přibylo také hodnocení z pozic podnikových manažerů. Výčet sice zdaleka není úplný, ale snaha o objektivní posouzení výkonu škol je zřejmá. Jsou formovány nástroje, jejichž cílem je hodnotit kvalitu studia na vysokých školách. (Např. „Benchmarking in Higher Education",CHEMS /The Commonwealth Higher Education Management Servicel, vydalo UNESCO roku 1998.) Existují rozličné rankingové postupy, např. velmi známý Academic Ranking of Word Universities (ARWU, Šanghaj), jenž měři kvalitu vysoké školy vědní úspěšností, ale časté jsou i rankingové metody založené na hodnocení úspěšnosti při hledání zaměstnání (InterStudent). Ranking britských Times/ů jako kritérium využívá hodnocení akademických expertů a zaměstnavatelů. Ten se nám pro Evropu i pro anglosaskou část světa jeví jako adekvátnější. Proces evaluace kvality vyššího školství v Evropě není, a v současné době ani nemůže být, sjednocený. Stále se v něm uplatňuje také původní systémové paradigma, některé odlišné funkce tří základních soustav vyššího vzdělávání: středoevropské, francouzské a britské. Při rozboru této situace si uvědomujeme, že existuje sjednocující a poměrně objektivní cesta posouzení výkonnosti škol, a tou je hodnocení kvality edukace (či diplomu, certifikátu) zaměstnavatelem, tj. subjekty trhu práce. Nositelem této činnosti mohou být nejspíše personální a náborová oddělení zaměstnavatelů. Uznáváme, že zobecnění je značně široké, vztahuje se především na schopnost uplatnění nabytých znalostí. Nám se jeví jako objektivně a systémově použitelná metoda, komplexní úhel pohledu, jehož využitelnost daleko přesahuje rámec Evropy. Tento přístup k otázkám hodnocení kvality vzdělávání navíc umožňuje využívat celou škálu témat: hodnocení celkové připravenosti nositele kvalifikace (prredevším tzv. „skills“), ale z dílčího úhlu také např. teoretickou úroveň nositele kvalifikace a schopnost její aplikace, práce s IT apod.

My se v této studii zaměřujeme na vývoj vztahu mezi edukací a sektorem práce ve smyslu obecných požadavků na absolventy vysokých škol, na jeho vývoj od poloviny 20. století do současnosti, tedy do období formování tzv. deskriptorů v Evropské unii. Vztah práce a sektoru vzdělávání je v Evropě dán také charakteristikami sociálního státu a jeho usilováním o maximální zaměstnanost a zaměstnatelnost absolventů škol. Metody založené na počtu vědeckých studií a množství nositelů Nobelovy ceny patří do jiné kategorie. Není ovšem vyloučeno, že jsou ukazatelem vývoje struktury vzdělávání ve smyslu vytváření nejspíše vědecko-výzkumných institucí mimo rámec tradičních univerzit. Pozorujeme totiž dvojí tendenci: formování nadstandardu (exkluzivní výzkumné a vzdělávací instituce) a paralelně s nimi vytváření nízkonákladových fakult („low-costs“) i v rámci vysoce uznávaných univerzit (Harvard) - ty druhé jsou spojeny se snižováním nákladů (e-learning) a zpř́ístupněním vyššího vzdělávání širšímu okruhu zájemců (ŠUSTEK, 2004, s. 15-26). Vývoj oblasti celoživotního vzdělávání nedovoluje prozatím činit závěry pro budoucnost.

Relevantní informace a data pro náš postup získáváme především v kontextu jiných výzkumů, kde bývají často jen podkapitolou k hlavnímu tématu. Je tomu tak i ve studiích Coombse, Bourdieu, Passerona, Teichlera. Jejich práce používáme pro definici vývoje vzdělávání a jeho kvality. Coombs představuje americké bádání v oblasti vývoje vzdělávacích soustav, Bourdieu s Passeronem jsou Francouzi: sociologové, sociolingvisté, ale v první řadě znalci kontextu studentsko-dělnických revolt ve Francii na konci 60. let. Teichler je mezinárodně uznávaný odborník na otázky edukace a zaměstnávání s působištěm v Německu. Od roku 
1997 do roku 2001 byl prezidentem Společnosti pro vysokoškolské vzdělávání v Evropě (European Higher Education Society/EAIR), ale záběrem svých prací přesahuje kontinentální evropské školství. K úrovni či kvalitě vzdělávání se svým osobitým a značně futurologickým pojetím vyjadřuje Toffler (TOFFLER, 1992 , s. 28). Projektuje „šok z budoucnosti“, k němuž dle jeho předpokladů dojde následkem nepřipravenosti současných generací na prudké změny ve vývoji technologií. Tvrdí: „Právě nepochopení tohoto principu vysvětluje, proč jsou vzdělávací systém a psychologie tak nebezpečně neschopné připravit lidi na úspěšné fungování v superindustriální společnosti“. Za humboldtovské tradice hovoří v prvním desetiletí 21. století profesor vídeňské univerzity Liessmann (LIESSMANN, 2010). Jeho ostrá kritika současného stavu vysokého školství je vedena z pozic ideálů středoevropské univerzity. Vysokoškolskou politikou v období 90. let se zabývá vědecký tým Leo Goedegebuura z prostředí nizozemské univerzity v Twente. Za Českou republiku jsou pro nás vodítkem Průcha, Kohoutek, Jochman a pro speciální otázky řada dalších. Stejně tak se v textu obracíme na jiné odborníky, z nichž mnozí řeší již specifické aktuální problémy kvality vzdělávání ve vztahu k požadavkům trhu práce (podnikům), což je téma, do kterého se rozhodujícím způsobem promítá uplatnění absolventských profilů na trzích práce: jsou to Boys, Brennan, Kogan, Sanyal Bicas, Trow, Desmarez, Thys-Clément a další. Tito odborníci se věnují otázkám využitelnosti vysokoškolské kvalifikace ve světě práce již od poslední třetiny minulého století. Žádný $\mathrm{z}$ nich není ve svých výzkumech svázán výlučně s poválečnými desetiletími. Trow v roce 1974 poukazuje na to, že růst vysokoškolského vzdělávání nevyhnutelně vede spíše ke kvalitativním změnám než jen ke kvantitativním. Poválečné školství popisuje jako přechod od „elitního“ k „masovému“ (...has pointed out that the growth of higher education leads inevitably to qualitative rather than merely quantitative change). Jeho definici a Coombsovu charakteristiku tohoto období (viz dále) považujeme za postačující pro účely našeho výkladu. Fulton, Gordon a Williams (FULTON, GORDON, WILLIAMS, 1982, s. 25) ve své studii hovoří také o metodách plánování požadavků na kvalifikovanou pracovní sílu, ale je to spíše problém direktivně řízených soustav šedesátých a sedmdesátých let. Uvedení autoři však ve svých studiích pojednávají o celoživotním vzdělávání.

V současnosti diskutované otázky kvality vyššího vzdělávání se dotýkají různých témat. Goedegebuure cituje Brennana (BRENNAN, 1987), který se vyslovuje k tomu, zda je pojem kvality absolutní, nebo jen relativní. Kvalita je z pohledu tohoto autora jen relativní multidimensionální koncept, daný interpretací a kontextem (Die Qualität der Hochschule kann nur in Relation zu bestimmten Zielen definiert werden.) (GOEDEGEBUURE, 1992). Již dříve se o absolutním a relativním pojetí posuzování vysokých škol vyslovil Birnbaum (BIRNBAUM, 1983). My sdílíme toto stanovisko, protože pojednávat o kvalitě vysoké školy je velmi obtížně uchopitelný úkol, který nabízí množství témat, jejichž řešení by si vyžadovalo spolupráci řady odborníků - například voblasti srovnávací pedagogiky, ale rovněž sociologie, ekonomiky, psychologie, demografie apod. Domníváme se, že jejich závěry by byly asi snadno zpochybnitelné. Také Coombs upozorňuje na složitost posuzování kvality vzdělávání v rychle se měnícím současném světě.

Stížnosti na upadající kvalitu vzdělávání sahají hluboko do antických kultur (Sokratův spor se sofisty), v padesátých letech 20. století zápas obránců latiny a řečtiny jako podmínky pro přijetí ke studiu na univerzitě. Coombs dospívá $\mathrm{k}$ dnes již široce uznávanému názoru, že nemá smysl odvolávat se při posuzování kvality edukace na absolutní hodnoty, tj. nadčasové hodnoty (But it is also possible that the critics, like Don Quijote, are tilting at statistical windmills.) Chybu spatřuje rovněž ve snahách kritizovat či hodnotit kvality studia bez ohledu na různost systémů vzdělávání. S tímto stanoviskem souhlasíme a předpokládáme, 
že v současnosti je nejpoužitelnějším kritériem hodnocení kvalit absolventů škol jejich odborná využitelnost v konkrétních zaměstnáních, tj. na trzích práce. Námitka, že kvalitu diplomu nemůže posuzovat zaměstnavatel, neobstojí. Právě určité pracovní prostředí může důkladně prověřit váhu běžného diplomu: ten nemusí nic vypovídat o osobnosti držitele.

Je na místě zmínit rovněž, že do určité míry je kvalita vysoké školy dána genetickou výbavou studujících, tedy individuálními biologicko-psychologickými vstupy. Toto téma je většinou obcházeno, snad i oprávněně - inteligence a mentální předpoklady jsou chápány už jinak, než jak tomu bylo před dvěma třemi generacemi, uplatñuje se pojem více - násobných inteligencí (GARDNER, 1999). Zjednodušeným výkladưm a aplikacím inteligence se vyhýbal již Alfred Binet, který na základě státní objednávky jako první začíná měřit mentální dispozice. (Francouzské Ministerstvo školství tehdy rozhodlo, že vřazování dětí do zvláštních škol musí být objektivně zdůvodňováno.) Standardní interpretace dotazníkových průzkumi inteligence využil včeském prostředí rovněž Dr. Rudolf Mudroch, který v meziválečném Československu prováděl výzkum schopností pro učení a studium u různých věkových kategorií (MUDROCH, 1930). Jeho vlastní metodou pro interpretaci byly korelace školního prospěchu a psychologického šetření. Korelace sice obecně naznačují vysoký stupeñ shody prospěchu a psychických dispozic, ale Mudrochovy interpretace jsou dobově idealistické. Citujeme: „...podle tohoto vyšetření, jehož, věrohodnost jsem se snažil doložit, bylo by třeba vyloučiti ze studií $12,5 \%$ pražských žáků kvart a kvint pro nepostačující schopnosti rozumové. Kolik dalších by jich přibylo, kdybychom měli ještě paralelní vyšetření lékařské a sociální, netroufám si odhadnouti. "Mudroch nebere vúvahu sociální zázemí studujících a společensko-ekonomickou situaci v zemi vübec. Ostatně ani Toffler v90. letech téhož století nepovažuje sociální hledisko za podstatné. Chudí jsou pro něho ménè mobilní a méně výkonní (TOFFLER, 1992, s. 61-63). Jen málo se u iniciátorů měrení inteligence bere vúvahu motivace. (V současnosti někteři v praxi působící sociologové a psychologové pochybují, zda lze dostatečně účinně motivovat behaviorálně, „zevně“. Motivaci, sociální kompetenci a týmovou práci považuje za mýtus např. Řezníčková (̌̌EZNÍČKOVÁ, 2010) z firmy CONSIM.

Pro názornost předkládáme jeden z Mudrochových korelačních testi̊:

Tabulka č. 1 Korelace školního prospěchu a genetických dispozic

\begin{tabular}{|l|c|c|c|c|c|}
\hline $\begin{array}{l}\text { Psychologický } \\
\text { posudek: }\end{array}$ & \multicolumn{5}{|c|}{ Prospěch školní } \\
\hline Ke studiu: & Výborný & dobrý & $\begin{array}{c}\text { dobrý- } \\
\text { dostatečný }\end{array}$ & Dostatečný & nedostatečný \\
\hline Velmi způsobilí: & $45 \%$ & $25 \%$ & $17 \%$ & $12 \%$ & $3 \%$ \\
\hline $\begin{array}{l}\text { Dobře } \\
\text { způsobilí: }\end{array}$ & $13 \%$ & $20 \%$ & $23 \%$ & $33 \%$ & $9 \%$ \\
\hline Způsobilí: & $1 \%$ & $19 \%$ & $19 \%$ & $42 \%$ & $19 \%$ \\
\hline Slabě zpơsobilí: & $--\%$ & $10 \%$ & $16 \%$ & $51 \%$ & $22 \%$ \\
\hline Nezpůsobilí: & $--\%$ & $(10 \%)$ & $(20 \%)$ & $(40 \%)$ & $(30 \%)$ \\
\hline
\end{tabular}

Zdroj: MUDROCH, R. Otázka výběru studovaného dorostu, s. 1-5 


\section{Vývoj hodnocení kvality vysokoškolských diplomů světem práce}

V úvodu jsme pro naši práci označili charakteristiku přechodu od elitního vzdělávání k masovému za výchozí (TROW, 1974, s. 4.). Na tuto definici se odvolává i Goedegebuure (GOEDEGEBUURE, 1992) - podle něho je Trow autorem myšlenky, a píše, že Trow nepovažuje obtíže vysokých škol za problémy jednotlivých škol či skupin škol, ale za proces, který se uskutečňuje ve všech moderních společnostech. Jeho přínos systematizaci vysokoškolského vzdělávání patří mezi základní kritéria hodnocení vývoje vyššího vzdělávání po druhé světové válce. Desmarez a Thys-Clément hovoří již v šedesátých letech o nedostatečných dovednostech u absolventů škol. (Nor has this concern been unique to France. During the same period, the skill shortages was an issue in many other countries, including the Federal Republic of Germany, the United Kigndom, Sweden, the United States, Canada and Belgium. Indeed, it was on the agenda of the 1961 International Labour Conference/ILO/1960). V šedesátých letech však otázka tvrdých a měkkých „skills“, respektive jejich nedostatku na trhu zaměstnávání, nehrála takovou roli jako v 90. letech.

Máme k dispozici řadu studií, které dokládají růst počtu škol i rychle se zvyšující počty studujících v průběhu druhé poloviny 20. století. Některé výzkumné zprávy vedou napříč politickými systémy a ukazují takto na shody ve vývoji školství různých společenských zřízení. Poměrně přesvědčivě to vyplývá ze srovnání počtu studujících vysokých škol ze Spolkové republiky Německo, Německé demokratické republiky, Mad'arska, Nizozemska, Polska, Rumunska a Švédska. Tato průřezová data, tj. napříč různými společenskými zřízeními, čerpáme ze studie O. Fultona, A. Gordona, G. (FULTON, GORDON, WILLIAMS, 1982):

Tabulka č. 2 Růst počtu studujících mezi lety 1950 a 1965

\begin{tabular}{|l|c|c|c|c|}
\hline Země & Rok & Počet & Rok & Počet \\
\hline $\begin{array}{l}\text { Spolková republika } \\
\text { Německo }\end{array}$ & 1950 & 128000 & 1965 & 300000 \\
\hline $\begin{array}{l}\text { Německá demokratická } \\
\text { republika }\end{array}$ & 1951 & 76000 & 1965 & 300000 \\
\hline Mad'arsko & 1950 & 25981 & 1965 & 57482 \\
\hline Nizozemsko (Nizozemí) & 1950 & 27736 & 1965 & 64409 \\
\hline Polsko & 1950 & 117506 & 1965 & 152362 \\
\hline Rumunsko & 1950 & 52007 & 1965 & 71989 \\
\hline Švédsko & 1950 & 16887 & 1965 & 77752 \\
\hline
\end{tabular}

Zdroje: ILO/CEPES: NSR: Hüfner et al., 1977; NDR: Sachre, 1977; Hungary: Ivan, 1977; Nizozemsko: Ritzen, 1977; Polsko: Kluczynski and Jozefowicz, 1977; Rumunsko: Pestisano et al., 1977; Švédsko: Bergendal, 1977; UNESCO, 1960; UNESCO, 1975; UNESCO, 1977.

Srovnání je přesvědčivé. Za patnáct let (1950/1 - 1965) se stavy studujících až zdvojnásobují, v Polsku a Rumunsku se zvyšují zhruba o třetinu.

Mohutný rozmach vzdělávání v prvních desetiletích po válce vyvolával pocit, že bude pokračovat dokud nenaplní své cíle - odstranění analfabetismu, posílení všech stupňů vzdělávání, zásadní zlepšení kvality života obyvatel všech zemí. Tento proces měl a dosud má 
- alespoň politicky - značnou prosociální orientaci. Tímto směrem se ubíralo rovněž myšlení v úspěšných západních ekonomikách.

Proces rychlého budování nástrojů edukace za současného přitakávání pracovních trhů pokračuje do poloviny šedesátých let, kdy se prosazuje nový názor, přesněji nové chápání souvislostí: na širším základě se to stalo již roku 1965 na konferenci ve Williamsburgu (Virgínie), o níž informuje námi často citovaný a jmenovaný Philips H. Coombs. Jeho přednáška byla klíčovým tématem konference a ve studii Světová krize ve vzdělávání (COOMBS, 1985) otevřeně mluví o krizi vzdělávání, nastupujícím celosvětovém kolapsu edukace. Coombs upozornil na masovost vzdělávání a jeho následné komplikace jinými slovy než Trow. Syntetizoval dílčí zprávy o vývoji národních vzdělávacích systémů ve výše uvedené studii: (,Since 1945, all countries have undergone fantastically swift enviromental changes, brought about by a number of concurrent worldwide revolutions - in science and technology, in economic and political affairs, in demographic and social structures. Educational systems also grown and changed more rapidely than ever before. But they have adapted all too slowly in relation to the faster pace events on the move all around them. The consequent disparity - taking many forms- between educational systems and their environments is the essence of the worldwide crisis in education").

V Evropě tento proces kulminuje již zmíněnou mohutnou studentskou revoltou, která se z Francie šíríla po celém kontinentu. Událostmi, které probíhají od druhé poloviny šedesátých let, končí dle našeho názoru první období, etapa přechodu od elitního k masovému vzdělávání, uskutečňovanému v rámci silné sociální kritiky poměrů na vysokých školách. Elitářství a výlučnost vysokých škol musely ustoupit stále početnějšímu proudu nových uchazečů o studium. Dlouhodobým důsledkem válek v první polovině dvacátého století je tedy hluboká demokratizace společnosti, především západo- a stř̌edoevropské.

Rok 1968 považujeme proto za mezník, ve kterém kulminuje sociální kritika vzdělávacích systémů. Kvalita vzdělávání není zásadně zpochybňována, a pokud ano, tak především na základě kvantitativních ukazatelů, což jsou nepostačující kapacity škol (posluchárny, nedostatek učitelů, omezený přístup k službám apod.), je diskutován problém sociální struktury studujících. Za vzdělání je považován především tradiční nácvik vědomostí. Dochází ke střetnutí starých univerzitních tradic, které vytvářely z vysokých škol monolitní centralizované útvary, se studenty, jejichž argumentace byla často nejasná a nepřesná, avšak způsobila, že autorita fakultních pedagogických sborů byla otřesena a hroutila se. Jsou zakládány provizorní společné komise vyučujících a studujících. Maurice Duverger píše 16. května 1968 v Le Monde“: „, v těchto improvizovaných komisích, kde vyučující a studenti dnem i nocí diskutují, rozvíjí se základní novinka: radikální transformace vztahů mezi profesory a posluchači, která - pokud se uskuteční - bude znamenat opravdovou revoluci.“

Od okamžiku, kdy se ze studia na vysoké škole stala masová záležitost, ztrácí značně na významu sociálně třídní problém, z něhož vychází Bourdieu a mnozí jiní. Problém má samozřejmě svoji setrvačnost, takže ještě v roce 1996 Oskar Anweiler, ve studii Bildungssysteme in Europa, v kapitole o Francii (ANWEILER et al., 1996), nepovažuje zvýšení počtu studentů z dělnických rodin z 6,7 \% roku 1960 na 16,6 \% roku 1990 za nepochybný indikátor sociálních změn a demokratizace. (Počet dělníků na celkový počet obyvatel poklesl v uvedeném období ze $49 \%$ na $40 \%$.)

V první polovině 90. let však nastává změna hodnotové orientace. V článku „Francouzi se smiŕrili s penězi“ (Les Français réconcilliés avec l'argent- L’État de la France 1994-5) se 
dovídáme, že ,peníze, po dlouhou dobu spojené s levicovou ideologií nerovnosti a vykořist'ování, byly v průběhu předcházejícího desetiletí rehabilitovány“. Proměny hodnotové orientace se však uskutečňují o desetiletí dříve, jak lze číst v Kellerově Soumraku sociálního státu:

Ve Francii $i$ v dalšich rozvinutých sociálních státech byly např́klad nejvyšši platy ještě $v$ šedesátých a sedmdesátých letech 20. století poměrně výrazně limitovány. To umožnovalo provádět redistribuci uvnitř masy námezdních a získávat zdroj pro výplaty nejnižších mezd pro nekvalifikované (SMIC) Mluvilo se tehdy o „neviditelné sociální politice“ firem. Naopak mladí lidé v té době akceptovali nižši platy, protože věděli, že s věkem a s léty odpracovanými u firmy jim porostou. Tím se podíleli na subvencování platů svých starších kolegů. To vše skončilo v osmdesátých letech 20. století, kdy rozdíly mezi platy začínají prímo astronomicky narůstat (KELLER, 2005, s. 99).

Myšlenka „ziskovosti““ jako kladné hodnoty se rychle šíríla. Rehabilitace bohatství (peněz) prochází opět všemi kontinenty a je provázena předpokládaným zánikem ideologií a direktivním způsobem řízených státních celků. Jako alternativa se vynořuje idea „občanské společnosti“ a „liberální demokracie“ (HUNTINGTON, 2007). Zcela nekonfliktně vidí vývoj světového společenství Fukuyama (FUKUYAMA, 2004). Jen na okraj poznamenáváme, že postupné, ale rychlé zhodnocování vztahu k finanční úspěšnosti probíhá za současné demontáže sociálního státu.

Datum revolty francouzských studentů je pro nás jen orientační a symbolický předěl, jelikož průběh demokratizace a mohutného přívalu dalších a dalších zájemců o studium (s prof. Kohoutkem „masifikace“) se časovým rozpětím liší od systému k systému (či od regionu k regionu). Jedno je ovšem jisté: „masifikace“ do dnešního dne trvá.

Přebíráme tabulku z knihy Les Héritiers, kterou vydali autoři Bourdieu a Passeron a která názorně ukazuje jednak sociální rozvrstvení francouzských vysokoškoláků v první polovině 60. let, jednak dokládá způsob uvažování mnoha francouzských intelektuálů té doby. 
Tabulka č. 3 Školní úspěšnost podle sociálního původu

\begin{tabular}{|c|c|c|c|c|c|c|}
\hline \multicolumn{7}{|c|}{ Školní úspěšnost podle sociálního původu (přijetí na vysokou školu 1961-1962) } \\
\hline \multirow{2}{*}{$\begin{array}{l}\text { Sociálně } \\
\text { profesní } \\
\text { kategorie } \\
\text { rodičů }\end{array}$} & & \multirow{2}{*}{$\begin{array}{l}\text { Objektivní } \\
\text { změny } \\
\text { (možnost } \\
\text { přístupu) }\end{array}$} & \multicolumn{4}{|c|}{ Pravděpodobnostní údaje } \\
\hline & & & Právo & $\begin{array}{l}\text { Přírodní } \\
\text { vědy }\end{array}$ & $\begin{array}{c}\text { Humanitní } \\
\text { ob. }\end{array}$ & Lékařství \\
\hline \multirow{3}{*}{$\begin{array}{l}\text { Zemědělští } \\
\text { dělníci }\end{array}$} & $\mathrm{H}$ & 0,8 & 15,5 & 44,0 & 36,9 & 3,6 \\
\hline & $\mathrm{F}$ & 0,6 & 7,8 & 26,6 & 65,6 & 0 \\
\hline & Ens & $\mathbf{0 , 7}$ & 12,5 & 34,7 & $\mathbf{5 0 , 0}$ & 2,8 \\
\hline \multirow{3}{*}{ Zemědělci } & $\mathrm{H}$ & 4,0 & 18,8 & 44,6 & 27,2 & 7,4 \\
\hline & $\mathrm{F}$ & 3,1 & 12,9 & 27,5 & 51,8 & 2,9 \\
\hline & Ens & 3,6 & 16,2 & 37,0 & 38,1 & 5,6 \\
\hline \multirow{3}{*}{ Služby } & $\mathrm{H}$ & 2,7 & 18,6 & 48,0 & 25,3 & 7,4 \\
\hline & $\mathrm{F}$ & 1,9 & 10,5 & 31,1 & 52,6 & 4,7 \\
\hline & Ens & 2,4 & 15,3 & 41,3 & 37,0 & 5,5 \\
\hline \multirow{3}{*}{ Dělníci } & $\mathrm{H}$ & 1,6 & 14,4 & 52,5 & 27,5 & 5,0 \\
\hline & $\mathrm{F}$ & 1,2 & 10,4 & 29,3 & 56,0 & 2,6 \\
\hline & Ens & 1,4 & 12,3 & 42,8 & 39,9 & 3,6 \\
\hline \multirow{3}{*}{ Zaměstnanci } & $\mathrm{H}$ & 10,9 & 24,6 & 46,0 & 17,6 & 10,1 \\
\hline & $\mathrm{F}$ & 8,1 & 16,0 & 30,4 & 44,0 & 6,1 \\
\hline & Ens & 9,5 & 21,1 & 39,4 & 28,6 & 8,6 \\
\hline \multirow{3}{*}{$\begin{array}{l}\text { Majitelé prům. } \\
\text { obchod. podn. }\end{array}$} & $\mathrm{H}$ & 17,3 & 20,5 & 40,3 & 24,9 & 11,0 \\
\hline & $\mathrm{F}$ & 15,4 & 11,7 & 21,8 & 55,7 & 4,8 \\
\hline & Ens & 16,4 & 16,4 & 31,8 & 39,1 & 8,1 \\
\hline \multirow{3}{*}{$\begin{array}{l}\text { Střední } \\
\text { zaměstn. } \\
\text { vrstva }\end{array}$} & $\mathrm{H}$ & 29,1 & 21,0 & 38,3 & 30,2 & 8,5 \\
\hline & $\mathrm{F}$ & 29,9 & 9,1 & 22,2 & 61,9 & 3,4 \\
\hline & Ens & 29,6 & 15,2 & 30,5 & 45,6 & 6,0 \\
\hline \multirow{3}{*}{$\begin{array}{l}\text { Svobodná pov. } \\
\text { a vysoké úřed. }\end{array}$} & $\mathrm{H}$ & 58,8 & 21,8 & 40,0 & 19,3 & 14,7 \\
\hline & $\mathrm{F}$ & 57,9 & 11,6 & 25,7 & 48,6 & 6,5 \\
\hline & Ens & 58,5 & 16,9 & 33,3 & 33,2 & 10,8 \\
\hline
\end{tabular}

Zdroj: BORDIEU,P., PASSERON, J.C.: Les Héritiers, s. 13

Analytické studie (většinou autorských týmů), které jsme uvedli a které považujeme za klíčové, také nejsou zaměřeny pouze na první fázi vývoje vzdělávacích soustav - snad s výjimkou speciálních prací jako jsou Les Héritiers Bourdieu a Passerona, jejichž význam je posilován sociálně politickou a geografickou lokalizací.

\section{Disproporce mezi kvalifikací a trhem}

Práce, jež se vztahují k první vlně poválečného vzdělávání, většinou zahrnují také následující, tj. druhé období, které pracovně označujeme za „disproporci mezi kvalifikací a trhem“. Patří k nim také citované výzkumy a zprávy Fultona, Gordona, Williamse z roku 1982, kteří již berou v úvahu kvalifikaci ve vztahu k trhu práce a pojednávají o snaze brzdit vysokou poptávku po studijních možnostech kupř́kladu zaváděnými směrnými čísly (numerus clausus/fixus). Většinou dospívají k víceméně systémovému využití celoživotního vzdělávání, které chápou jako nástroj sociální rovnováhy a uplatnění ve světě práce (FULTON, GORDON, WILLIAMS, 1982, s. 16). 
Proti sobě stojí dvě závažná témata: doznívající optimistické a idealistické, které kromě jiného formuluje myšlenku nutnosti investic do vzdělávání jako nejvýnosnější ekonomické strategie; a druhé, které vidí stále silnější nesoulad mezi kvalifikací (profesí) a uplatněním na trhu práce. Obě tyto koncepce platí - v různých obměnách - do současnosti. Jsou důležitým a svým způsobem nepostradatelným indikátorem kvality vysokého školství. V př́ipadových studiích týmu (SANYAL, 1987) Bicase C. Sanyal, které analyzují dvě pětiletá období (1978-83 a 1984-89), je zachycen nejen pozitivní obraz demokratizace (a masovosti) vysokoškolského vzdělávání, ale i jeho rub - zvyšující se počty nezaměstnaných vysokoškoláků. Napříště se společnost bude vyrovnávat především se strategiemi uplatnění absolventů vysokých škol na trzích práce. V míre uplatnitelnosti kvalifikací se implicitně projeví úspěšnost či neúspěšnost vysoké školy. Zaměstnavatelé kritizují vysoké školy z nedostatečné připravenosti absolventů vyrovnat se s požadavky konkrétních pracovišst'. Vztah mezi kvalifikací a naplněním požadavků trhu je aktualizován, i když je často využíván také politicky. Téma investic se promítá do sporů o tom, kdo má platit předpokládaný či jen domnělý vzdělanostní a dovednostní deficit absolventů vysokých škol. Do popředí se dostává adaptabilitaabsolventi̊ škol na požadavky pracoviště. Jsou silně akcentovány měkké a tvrdé dovednosti. Proti sobě stojí zvládání standardů, vlastní obsahy kurikula, a zvládání metod a postupů nutných pro realizaci úkolů pracovišt'.

Vývojem vysokého školství z hlediska uplatnění kvalifikací na trzích práce se komplexně zabývá Teichler. U Teichlera oceňujeme, že dovede zdůvodnit trvající zvláštnosti jednotlivých vzdělávacích systémů - vrací se k jejich tradičnímu dělení na středoevropský, francouzský a britský model - této klasifikace využívá ještě ve své studii z roku 2008, kterou vydal na univerzitě v Buenos Aires (Reforma vysokoškolského vzdělávání v Evropě, Latinské Americe a Japonsku) (TEICHLER, 2008). Také jeho předcházející komparativní studie respektuje zvláštnosti vzdělávacích soustav, tento záměr má i v samotném názvu Europäische Hochschulsysteme: Die Beharrlichkeit vielfältiger Modelle, 1990, Frankfurt/New York. Dělení na tři základní systémy vzdělávání tento text nevyjadřuje explicitně. Na prvním zasedání Konsorcia pro výzkum vysokého školství (1988) Teichler definuje stávající problémy mezi vysokoškolským vzděláváním a zaměstnáním a konstatuje...Kvalitativní vazby mezi obsahem vzdělávání a učením, dopad nezaměstnanosti a redukce pracovní doby na vztah mezi vzděláváním a zaměstnáváním, vyrovnání se s novými technologiemi, změna vztahu mezi vysokoškolským vzděláním a prací...na všechna tato témata je nutno klást di̊raz. "(BERKA aj., 1999).

Také Sanyal C. Bicas a kol. se vyjadřují k témuž tématu a hovoří o následujících změnách ve vztahu mezi kvalifikací a prací:

1. snižující se váha diplomů jako činitele určujícího profesní kariéru,

2. nastupující proces vertikální substituce, v němž nadbývající absolventi nastupují do míst obsazovaných předtím osobami bez vysokoškolských diplomů,

3. redukce výhod vysokoškolsky vzdělaných pracovníků ve smyslu odměňování, aniž by docházelo ke změnám ve vztahu mezi kvalifikací a profesním postavením (POUROVÁ, NEVŘALA, BERKA, 1998).

Bylo již řečeno, že sledujeme kvalitu vyššího vzdělávání obecně prostřednictvím vztahu mezi kvalifikací a jejím uplatněním ve světě práce, což považujeme za nejvhodnější a komplexní metodu, jak zvládat tento úkol. V době rychlých změn ve světě práce a povolání a za složitého vývoje sociálně politického kontextu nelze posuzovat kvalitu vyššího školství jen na základě idealisticky a svým způsobem i politicky vykonstruovaných kritérií. Vyslovili jsme již Goedegebuurovu myšlenku, kterou přebírá z Brennana, jenž se svým týmem 
(Brennan, J./Goedegebuure, L.C.J./ Shah, T./Westerheijden, D.F./Weusthof, D.J.M.) (GOEDEGEBUURE, 1992, s. 45) tvrdí, že kvality vysoké školy nelze vyvozovat hierarchicky, ale že by měly popisovat kvalitu různých systémů. Otázka, jak dalece se liší kvality v rámci jednoho systému a jak vně systému, je záležitostí empirického posouzení. Goedegebuure nemá pravděpodobně na mysli Teichlerem uznávané dělení, ale uvažuje obdobně jako on. My ve svém výzkumu doplňujeme hodnocení o realizaci systému vzdělávání (jeho produktu) ve světě práce. Kvalita studia je samozřejmě měřitelná i $\mathrm{v}$ jednotlivých případech a $\mathrm{z}$ dílčích pohledů, což mohou být ((individuálně) kvalifikace velmi nadaných či vysoce motivovaných studentů, kde rozdíly v úrovni školy nemusí (ale také mohou) hrát důležitou roli. Zde se uplatní i metody, které neberou v úvahu sektor práce jako prostředí ověřující validitu certifikátů. Analýza vývoje vzdělávání jako systému a ve společenském kontextu od poloviny 20 . století však prokazuje, že vysoké školství se trvale snaží odpovídat především na požadavky měnícího se trhu práce. Tento vztah je primární a nelze jej redukovat jen na kvalitu „studia o sobě“- nepochybujeme o tom, že se v rozbujelém prostředí řetězců vysokých škol skrývá značné množství průměrných či podprůměrných výkonů, individuálních i skupinových. Otázka je, do jaké míry jsou to nedostatky imanentního vývoje. Přestože nemusíme být úplně zajedno s konstatováním Sanyala C. Bicase, že charakteristickými rysy vztahu mezi vzděláváním a prací je snižující se váha diplomů, vertikální substituce a odbourávání výhod absolventů vysokých škol, jeví se nám tento popis jako adekvátní pro vývojové období, které je předmětem naší práce. Za ním se skrývá odpověd' zaměstnavatelů na upotřebitelnost vysokoškolských certifikátů.

Zjednodušeně a srozumitelně se k této již několik desetiletí diskutované otázce vyjádřil Porrer $\mathrm{z}$ univerzity $\mathrm{v}$ Edinburgu....,,dělat to, co svede dohromady absolventy a zaměstnavatele s cílem nalézt absolventưm vhodné zaměstnání" (BERKA, aj., 1999). Tato jednoduchá myšlenka se rovněž obrací na hodnotu certifikátů vysokých škol, přesněji na školní kurikulum. Zaměstnavatelé (trh) požadují, aby absolventi získali nástroje pro orientaci na trzích práce v oblasti intelektuálních a sociálních dovedností, což Porrer identifikoval ve své výzkumné zprávě (PORRER, 1994, s. 339-348). Určil 14 vzdělávacích cílů v rámci inženýrských oborů. Výchovné cíle rozdělil na intelektuální a sociální dovednosti:

Intelektuální dovednosti

- naučit inženýry, jak se vzdělávat a tvořivě myslet - do šířky, kvantitativně i kvalitativně,

- umožnit jim, aby se naučili zaujímat kritické a nezávislé soudy,

- vypěstovat $v$ nich schopnost zvažovat a modifikovat ve světle nových informací předcházející rozhodnutí,

- naučit je analyzovat a rozlišovat prvky v artefaktech, systémech i argumentech,

- vypěstovat $\mathrm{v}$ nich schopnost dokázat se vyrovnat s reálnými podmínkami, tj. umět využít a tolerovat v podmínkách nejistoty a časové tísně neúplné či nedokonalé informace.

Sociální dovednosti

- naučit inženýry vyjadřovat se a komunikovat jasně, důkladně a přesvědčivě, a to ústně i písemně, pomocí slov, čísel a dalších vhodných technik,

- dát inženýrům možnost, aby vedli schůze a účastnili se porad, včetně těch, které se týkají ne-inženýrů,

- vštípit jim vidění světa z pohledu lidí různých oborů, společenských vrstev, zájmů a kultur, 
- naučit je rozvíjet dobré pracovní vztahy a úspěšně kooperovat s řadou lidí na různých organizačních úrovních jak v podniku tak mimo něj,

- $\quad$ vypěstovat v nich schopnost a odvahu hledat změnu, pokud je žádoucí,

- vypěstovat $\mathrm{v}$ nich schopnost hledat a přebírat odpovědnost a delegovat ji na ostatní,

- vypěstovat v nich schopnost vybrat priority a organizovat práci.

Porrerův výzkum identifikuje nedostatky kurikula inženýrských oborů a je také indikátorem kvality vysoké školy - z pohledu zaměstnavatelské sféry. Je to obecný popis toho, co svět práce u absolventů inženýrských oborů postrádá, tj. schopnost uplatnit získané vědní a odborné poznatky, jejichž dobré zvládnutí se předpokládá. My v požadovaných intelektuálních a sociálních dovednostech vidíme také postupující sepětí vzdělávání a práce. Že Porrerova zjištění přesahují obory inženýrství a mají daleko širší platnost, prokazuje následný vývoj, směřující k rozvíjejícímu se boloňskému procesu a v prvním desetiletí 21. století k formování kritérií úrovně vzdělanosti - máme na mysli hlavně osm prozatím doporučovaných úrovní deskriptorů rámce evropských kvalifikací, které jako by navazovaly na výše uvedené intelektuální a sociální dovednosti edinburského výzkumu.

Porrerovu identifikaci můžeme pracovně považovat (od poválečné „masifikace“) za počáteční stadium třetího období vývoje analyzovaného vztahu vzdělávání a trhů práce. Výzkum definuje to, co vadí světu práce na kurikulech vysokých škol. Zároveň se do značné míry přesouvají tradiční úkoly sektoru práce, hlavně adaptace na pracovní pozice, do kompetence vzdělavatelů, tj. školství. Po letitých diskuzích bere školství tuto odpovědnost na sebe.

Na problémy zaměstnávání absolventů vysokých škol reagují v osmdesátých letech univerzity korporativně a u př́iležitosti 900. výročí založení univerzity v Boloni (1988) vydávají společný dokument „Magna Charta evropských univerzit“ (Bologna, 18. 9. 1988). Charta sice navazuje na tradiční univerzitní hodnoty, vyjdeme-li z naší předcházející analýzy, jeví se jako velmi pravděpodobné, že se jedná o reakci univerzit i na uplatnitelnost vysokoškolských diplomů v podnikové sféře. Tento princip je formulován na schůzce ministrů školství u př́ležitosti 800. výročí založení Pařížské univerzity (Sorbonna) jako potřeba harmonizovat architekturu evropského vysokoškolského systému. Pražská konference signatářu boloňských dohod (evropských ministrů školství) roku 2001 potvrzuje náš názor: vysokoškolský prostor evropského vzdělávání generuje praktické výstupy z jednání Sdružení evropských univerzit (European University Association, EUA) a projektuje:

- přijetí systému dobře srozumitelných a srovnatelných diplomů: dochází k dohodě o tom, že diplom bude mít dodatek, který jej učiní srovnatelným v rámci Evropy (dodatek k diplomu),

- přijetí systému vysokoškolského vzdělávání založeného na dvou cyklech: bakalářském a magisterském,

- uplatnění kreditů,

- podpora mobility,

- podpora evropské kooperace při evaluaci kvality,

- podpora evropské dimenze při výuce na vysokých školách.

Podpora evropské kooperace při evaluaci kvality směřuje přímo k řešení úrovně kvality evropských vysokých škol, nepríimo odpovídá na Porrerem naznačené požadavky na zkvalitnění kurikula ve prospěch podnikové sféry. Téměř přímo na ně odpovídají paralelně s Boloňským procesem vznikající deskriptory. Poměrně přesně vyjadřují, jakých kvalifikačních cílů mají dosáhnout jednotlivé vzdělávací stupně. Za vhodnější považujeme deskriptory o osmi úrovních. Citujeme z oficiálního textu Evropského rámce kvalifikací 
(http://ec.europa.eu/dgs/education_culture): „Deskriptory byly napsány tak, aby pokryly celou škálu výsledků učení, bez ohledu na výukový nebo institucionální kontext, a to od základního vzdělávání, přes úrovně školní a nekvalifikované dělnické úrovně až po doktorské nebo vrcholové profesionální úrovně. Pokrývají jak pracovní a studijní situace, tak akademické a profesní uspořádání, počáteční i další vzdělávání nebo přípravu, tedy všechny formy učení, at' už formální, neformální nebo informální. “ Evidentně jde o snahu vyrovnat úroveň vzdělávání nikoliv jen geograficky a interkulturně, ale také kvalitativně.

Jako př́klad dokládající kontinuitu vývoje požadavků trhu a následné odpovědi vzdělávací soustavy vybíráme deskriptory súrovní 6, která představuje zhruba první stupeň vysokoškolského studia (bakalář), a to jejich syntetizující část. Požadavky shodné s výstupy Porrerova výzkumu jsou patrné, shody uvádíme zvýrazněnou grafikou.

\section{Deskriptory: požadované kvalifikační úrovně EQF}

a) pokročilé znalosti $\mathrm{v}$ oboru práce nebo studia zahrnující kritické chápání teorií a zásad,

b) pokročilé dovednosti prokazující zvládnutí oboru a smysl pro inovace, jež jsou požadovány při řešení složitých a nepředvídatelných problémů ve specializované oblasti práce nebo studia,

c) řídit složité technické nebo odborné činnosti či projekty a nést odpovědnost za rozhodování v kontextu nepředvídatelné pracovní nebo vzdělávací náplně,

d) nést odpovědnost za řizení odborného rozvoje jednotlivců a skupin.

(Jde o zásady platné pro všechny vzdělávací úrovně vysokých škol, tedy rovněž pro magisterské a doktorské obory.)

\section{Závěr}

Naše analýza se zaměřuje na vztah vysokoškolského vzdělávání a trhu práce od konce druhé světové války. Věnuje pouze nezbytnou pozornost politickému a sociálnímu kontextu.

Máme-li shrnout podstatné body naší studie, pak považujeme za správné zdůraznit tři fáze vývoje hodnocení vysokoškolského vzdělávání, které se ve studii snažíme definovat v časovém rozsahu od konce padesátých let do současnosti.

1. fáze je období přechodu $\mathrm{k}$,,masifikaci“a v duchu vyrovnávání sociálních nerovností (demokratizace), kdy kvalita edukace není zpochybňována,

2. fáze je charakteristická disproporcí mezi kvalifikací a trhem: svět práce začíná zpochybňovat tradiční vzdělanostní profily,

3. třetí fáze již definuje požadavky na dovednosti (skills) jednak výzkumem (Porrer), jednak v jednotících dokumentech - například jako Evropský kvalifikační rámec (EQF).

Z pohledu deskriptorů i citované Porrerovy zprávy je patrné, že kvalitu vzdělání v rovině edukace a uplatnění kvalifikací na trhu práce určují především tyto cíle:

- kritické chápání teorií a zásad,

- smysl pro inovace,

- rešení složitých a nepředvídatelných problémů,

- rozhodování v kontextu nepředvídatelné pracovní nebo vzdělávací náplně. 
Považujeme výše uvedené kvalifikační úrovně za ilustraci obecné definice současných nároků na vzdělávání, jehož využitelnost je dána v první řadě výkonem praktických činností (trhem), jinými slovy adaptabilitou absolventů škol na pracovní prostř̌edí. Je nutno brát v úvahu i genetické a psychologické hledisko, protože tyto požadavky odpovídají určitým charakteristikám osobnosti. Je to otázka velmi složitá a umožňuje snadné sklouznutí do nerealistických až utopických výkladů. Zřejmé ovšem je, že dosavadní vzdělávání je založeno sice na systémovém, ale jinak kvantitativním poznávání různých vědních oborů. Uplatnění v teoretických i praktických oborech je dáno selektivně na základě individuálních motivací, ale značné množství pracovních pozic je obsazováno na jiném principu, iracionálně. K tomuto tématu zasvěceně píše německá socioložka Leuze (LEUZE, 2011).

Je zřejmé, že jde o proces rychlých změn, také z toho důvodu je měření kvalit vysoké školy ztíženo. Hodnota edukace měřená jejím uplatněním v praxi se nám však jeví jako nejspolehlivější, alespoň pro současný stav vývoje společnosti.

Na závěr bychom rádi upozornili, že celý vývoj kladení požadavků na kvalitu vysokého školství je poznamenán odkazy na celoživotní vzdělávání. Proto považujeme za užitečné, ne-li nutné zjišt’ovat, do jaké míry může tento vzdělávací systém kompenzovat některé absentující kvality vysokoškolské edukace. Není vyloučeno, že odpověd' na požadavek exkluzivní vzdělanostní úrovně vysokého školství nalezneme právě ve využití tohoto staronového systému. Tento problém považujeme za výchozí hypotézu pro další studium také kvalit vyššího vzdělávání.

\section{Literatura:}

[1] ANWEILER, O., et al. Bildungssysteme in Europa. Beltz -Verlag, Weinheim und Basel, 1996, 166 s. ISBN 34-0751-099-3.

[2] BERKA, O. aj. Úvod do vysokoškolského vzdělávání v Evropské unii. Karviná, 1999, 46 s. ISBN 80-7248-019-7.

[3] BIRNBAUM, R. Maintaining diversity in higher education. San Francisco: Josey Bass, 1983, 209 s. ISBN-0-87589-574-3.

[4] BORDIEU, P., PASSERON, J. C. Les Héritiers. Les étudiants et la culture. Paris: Minuit, 1964.

[5] BRENNAN, J. et al. Students, Courses and Jobs. In: The Relationships Between Higher Education and the Labour Market. London: Jessica Kingsley, 1987.

[6] BRENNAN, J. et al. Towards a Methodology for Comparative Quality Assessment in European Higher Education- a pilot study on economics in Germany, the Netherlands and the United Kingdom. London : Council for National Academic Awards, 1992.

[7] COOMBS, H. The World Crisis in Education, The view from the eighties. New York: Oxford, 1985, 353 s. ISBN 0-19-5035-038.

[8] DESMAREZ, P., TYS-CLÉMENT, F. Universities, Students and Employment. In: Higher Education Management and Policy, 6,3, 1994, ISSN 1682-3451.

[9] FUKUYAMA, F. Konec dějin a poslední člověk. Praha: Rybka Publishers, 2004, 379 s. ISBN 80-86182-27-4.

[10] FULTON, O., GORDON, A., WILLIAMS, G. Higher education and manpower planning. Geneva: ILO, 1982, ISBN 92-2-102973-5.

[11] GARDNER, H. Dimenze myšlení: teorie rozmanitých inteligencí. Praha: Portál, 1999, 389 s. ISBN 80-7178-2793. 
[12] GOEDEGEBUURE, L. Hochschulpolitik international. Trends-ProblemeLösungsansätze. Gütersloh: Bertelsmann Stiftung, 1992.

[13] http://ec.europa.eu/dgs/education_culture

[14] HUNTINGTON, S. Střet civilizací, boj kultur a proměna světového řádu. Praha: Rybka Publishers, 2007, 447 s. ISBN 80-86182-49-5.

[15] KELLER, J. Soumrak sociálního státu. Praha: Sociologické nakladatelství, 2005, 158 s. ISBN 80-86429-41-5.

[16] LEUZE, K. Zwischen Mythos und Mikropolitik: Soziale Kompetenz in der Wissensarbeit [online]. [cit. 2011-04-25]. Dostupné na WWW: <http:// metropolisverlag.de/Zwischen-Mythos-und-Mikropolitik\%3A-Soziale-Kompetenz-in-derWissensarbeit/11969/book.do>.

[17] LIESSMANN, K. P. Teorie nevzdělanosti. Praha: Academia, 2010, 127 s. ISBN 97880-200-1677-5.

[18] MUDROCH, R. Otázka výběru studovaného dorostu. Praha, 1930.

[19] PORRER, R. Placement as Integral part of Institutional Provision. In: Higher Education Management and Policy. 6,3,1994, ISSN 1682-3451.

[20] POUROVÁ, M., NEVŘALA, J., BERKA, O. Vysokoškolské poradenství a vzdělávání $v$ Evropě (Tempus S_JEP -11233). Karviná: SU OPF, 1998, ISBN 80-7248-005-7.

[21] PRŮCHA, J. Vzdělávání a školství ve světě: základy mezinárodní komparace vzdělávacích systémů. Praha: Portál, 1999, 319 s. ISBN 80-7178-290-4.

[22] ŘEZNÍČKOVÁ, R. Motivace, kompetence a týmová práce: realita versus moderní mýty [online]. Praha: CONSIM, s.r.o. [cit. 2011-09-20]. Dostupné na WWW: <http:// consim.cz/download/CSQ_Reznickova.pdf>.

[23] SANYAL, B. C. An International Comparative Analysis.(UNESCO) The Flandr Press, 1987.

[24] ŠUSTEK, E. a kol. Úvod do vysokoškolského vzdělávání v Evropské unii. Karviná, 1999, ISBN 80-7248-019-7.

[25] ŠUSTEK, E. Rámec vysokoškolského poradenství. In Acta academica karviniensia, Karviná: SU OPF, 2,2004, ISSN 1212-415X.

[26] TEICHLER, U. Reformas de los modelos de la educación superior in Europa, Japón y América Latina: Análisis comparados. Madrid/Buenos Aires: Mino y Davila, 2008, ISBN 10 84-96571-04-1, ISBN 13 978-84-96571-04-4.

[27] TEICHLER, U. Europäische Hochschulsysteme: Die Beharrlichkeit vielfältiger Modelle. Frankfurt/New York: Campus 1990, ISBN 3-593-34238-3.

[28] TOFFLER, A. Šok z budoucnosti. Praha: Práce, 1992, 284 s. ISBN 802080160X.

[29] TROW, M. Problems in the Transition from Elite to Mass Higher Education. In: Politics for Higher Education. Paris, OECD, 1974.

\section{JEL J08}

\section{PhDr. Oldřich Berka, Ph.D.}

vědecký pracovník Katedry společenských věd Obchodně podnikatelská fakulta v Karviné Slezská univerzita v Opavě Univerzitní náměstí 1934/3, 73340 Karviná berka@opf.slu.cz 


\section{Mgr. Pavla Sýkorová}

asistent Katedry marketingu

Obchodně podnikatelská fakulta v Karviné

Slezská univerzita v Opavě

Univerzitní náměstí 1934/3, 73340 Karviná

sykorova@opf.slu.cz

doc. Ing. Emanuel Šustek, CSc.

docent Katedry marketingu

Obchodně podnikatelská fakulta v Karviné

Slezská univerzita v Opavě

Univerzitní náměstí 1934/3, 73340 Karviná

sustek@opf.slu.cz 